\title{
Metabolism and requirements for calcium and phosphorus in the fast-growing chicken as affected by age
}

\author{
Arie Bar*, Dmitry Shinder, Sara Yosefi, Eliaho Vax and Isaac Plavnik \\ Institute of Animal Science, Agricultural Research Organization, the Volcani Center, Bet Dagan, Israel
}

(Received 30 April 2002 - Revised 30 August 2002 - Accepted 11 September 2002)

\begin{abstract}
Three series of experiments were conducted with fast-growing chickens in order: to evaluate the effects of dietary $\mathrm{Ca}$ and $\mathrm{P}$ on cholecalciferol metabolism and expression; to determine dietary $\mathrm{Ca}$ requirements; to determine dietary $\mathrm{P}$ requirements. The results of the first series confirmed previous results on the effects of dietary $\mathrm{Ca}$ and $\mathrm{P}$ on some variables of vitamin $\mathrm{D}$ metabolism and expression, Ca homeostasis and $\mathrm{P}$ metabolism in the young chicken (1- to 21-d-old), and extended them to older birds (22- to 43-d-old). The bone formation rate and the duodenal calbindin content were maintained at high levels until the age of $43 \mathrm{~d}$. Dietary Ca or P restriction increased duodenal calbindin and decreased bone ash in both 22- and 43-d-old chickens, but the effect on bone ash was less pronounced in the 43-d-old birds than in the younger ones. These results suggest that: (a) the capabilities for adaptation to dietary $\mathrm{Ca}$ and $\mathrm{P}$ restriction remain high during the whole growing period; (b) the growing broilers express a high adaptive capability even when the diet contains the recommended $\mathrm{Ca}$ and $\mathrm{P}$ contents. The results of the second and third series of experiments suggest that: (c) unlike the Ca requirements of the 1- to 22-d-old chick, $P$ requirements for growth and bone ash are similar, and are as high in the older chicks as in the younger ones $(7.4-8.3 \mathrm{~g} \mathrm{P} / \mathrm{kg}$ or $4.8-5.7 \mathrm{~g}$ non-phytate $\mathrm{P} / \mathrm{kg}$ diet); (d) although growth and bone ash in the 29- to 43-d-old chickens appear to be less sensitive to dietary $\mathrm{Ca}$ content, within a range close to the calculated $\mathrm{P}$ requirement, $10 \mathrm{~g} \mathrm{Ca} / \mathrm{kg} \mathrm{diet}$ appears to be required for best tibia mineralization, and to a lesser extent for better growth at this age.
\end{abstract}

Bone: Growth: Calbindin: Cholecalciferol: 1-Hydroxylase

Chicken growth has been accelerated enormously during recent decades (Havenstein et al. 1994), and there has been a matching increase in bone mass. Thus, the $\mathrm{Ca}$ regulatory system has become stressed to accommodate the increased $\mathrm{Ca}$ and $\mathrm{P}$ needs. Insufficient supplies of these two minerals reduce growth rate and bone calcification, and excess $\mathrm{Ca}$ intake also induces similar, but moderate reductions in growth and bone ash (Shafey et al. 1990; Hurwitz et al. 1995). Because of feedback relationships, various components of the regulatory system, such as kidney 25 hydroxycholecalciferol-1-hydroxylase (1hydroxylase), intestinal calbindin, and plasma $\mathrm{Ca}, \mathrm{P}$ or 1,25 dihydroxycholecalciferol $\left(1,25(\mathrm{OH})_{2} \mathrm{D}_{3}\right)$, are markedly influenced by the rate of growth (Bar \& Hurwitz, 1981; Hurwitz et al. 1995). Modulation of growth, by energy intake, genetic selection, sex, ambient temperature changes, or age, alters the response of the fast-growing chicken to dietary Ca (Bar \& Hurwitz, 1981; Hurwitz et al. 1995) or $\mathrm{P}$ (Orban \& Roland, 1990; Shafey et al. 1990) content. Some of these responses tend to be affected similarly by dietary $\mathrm{Ca}$ and $\mathrm{P}$ contents; others are affected differently by the respective minerals. For instance, intestinal absorption of $\mathrm{Ca}$ and $\mathrm{P}$ is induced by $1,25(\mathrm{OH})_{2} \mathrm{D}_{3}$. Ca or $\mathrm{P}$ depletion increases plasma $1,25(\mathrm{OH})_{2} \mathrm{D}_{3}$, but only $\mathrm{Ca}$ depletion induces kidney 1-hydroxylase activity in birds (Friedlander et al. 1977; Montecuccoli et al. 1977; Bar et al. 1982). Plasma Ca modulates parathyroid hormone secretion, which, in turn, affects renal $1,25(\mathrm{OH})_{2} \mathrm{D}_{3}$ formation; the latter and parathyroid hormone cause the bones to release $\mathrm{Ca}$ and $\mathrm{P}$ into the circulation. However, whereas the renal reabsorption of both minerals is affected similarly by $1,25(\mathrm{OH})_{2} \mathrm{D}_{3}$, parathyroid hormone has contrary effects on the two minerals (for reviews, see Fitzpatrick \& Bilezikian, 1996; Kumar, 1997; Wasserman, 1997). As a result of the above differences, the fast-growing chicken may exhibit anti-homeostatic responses, such

\footnotetext{
Abbreviations: BW, body weight; 1-hydroxylase, 25 hydoxycholecalciferol-1-hydroxylase; NRC, National Research Council; 1,25(OH) $2 \mathrm{D}_{3}$, 1,25 dihydroxycholecalciferol.

* Corresponding author: Dr Arie Bar, fax +972 8 9475075, email ariebar@agri.gov.il
} 
as increased $\mathrm{Ca}$ absorption associated with $\mathrm{P}$ deficiency, which may aggravate the hypercalcaemia and may damage the kidney (Page et al. 1979).

Our previous study (Hurwitz et al. 1995) focused on the interactions between growth, and dietary $\mathrm{P}$ and $\mathrm{Ca}$ homeostasis and requirements in the young (1- to 21-d-old) growing chick. Less attention was given to the older chicken, although its $\mathrm{Ca}$ and $\mathrm{P}$ consumption and consequently its $\mathrm{P}$ excretion to the environment are greater. Furthermore, leg disorders associated with cholecalciferol, $\mathrm{Ca}$ and $\mathrm{P}$ have become more widespread and severe in the older chicken (Riddle, 1991; Sorensen et al. 2000). Thus, in addition to the economic implications, $\mathrm{Ca}$ and $\mathrm{P}$ imbalance may also impair chicken welfare.

Previous publications have suggested that ageing decreases the basal metabolism and expression of cholecalciferol (as indicated by the changes in calbindin synthesis) in chickens (Bar \& Hurwitz, 1981), and diminishes the adaptive capability of cholecalciferol metabolism and expression in mammals (Armbrecht et al. 1998, 1999) and in laying hens (Bar \& Hurwitz, 1987). However, it is not yet clear whether the adaptive capability of a chicken is also impaired within the rearing period of 6 to 7 weeks.

Despite the marked acceleration in chicken growth during the last decade, the NRC's recommendations for dietary $\mathrm{Ca}$ and $\mathrm{P}$ for chicks at the ages $1-21,22-42$ and $43-56 \mathrm{~d}$ (10, 9.0 and 8.0, and 4.5, 3.5 and $3.0 \mathrm{~g} \mathrm{Ca}$ and non-phytate $\mathrm{P} / \mathrm{kg}$ diet, respectively) have not changed (National Research Council, 1994). Since 1994 only a few relevant papers have been published focusing mainly on $\mathrm{P}$ requirements for the young broiler, with special attention paid to decreasing the recommended $\mathrm{P}$ allocation by supplementing the diet with $1,25(\mathrm{OH})_{2} \mathrm{D}_{3}$, phytase, or both (for example, Mitchell \& Edwards, 1996; Waldroup et al. 2000). In these and in other studies the NRC recommendations on $\mathrm{Ca}$ and $\mathrm{P}$ contents (National Research Council, 1994) were accepted. A few other publications (Hurwitz et al. 1995; Rao \& Reddy, 1999) addressed the reassessment of the recommendations, especially those for $\mathrm{Ca}$, although $\mathrm{Ca}$ appeared to be less threatening to the environment than $\mathrm{P}$. Therefore, the present study aimed: (a) to extend the evaluation of the effects of age on $\mathrm{Ca}, \mathrm{P}$ and cholecalciferol metabolism and expression; (b) to determine the requirements for $\mathrm{P}$ in the fast-growing chick during the whole rearing period. In the light of the $\mathrm{Ca}-\mathrm{P}$ interrelationships, the secondary aim was: (c) to determine the requirements for $\mathrm{Ca}$ in the 29- to 42-d-old fast-growing chicken.

\section{Materials and methods}

\section{Animals}

Day-old Cobb chicks were obtained from a commercial hatchery. The chicks were raised in battery brooders situated in windowless constant-temperature rooms at $24^{\circ} \mathrm{C}$, with continuous fluorescent lighting. At the age of $29 \mathrm{~d}$ the chicks were transferred to individual cages in a similar room at $20^{\circ} \mathrm{C}$. Until the beginning of the experiments, all birds received standard diets, designed to satisfy the recommendations of the National Research Council (1994) except for $\mathrm{Ca}$ and $\mathrm{P}$. At the beginning of the experiments, the chicks were divided into the experimental groups with the aid of a computer algorithm that equalized both average

Table 1. Composition of the basal experimental diets

\begin{tabular}{|c|c|c|c|c|}
\hline \multirow{2}{*}{$\begin{array}{l}\text { Age (weeks)... } \\
\text { Basal diet... }\end{array}$} & \multicolumn{2}{|c|}{$1-4$} & \multicolumn{2}{|c|}{5 and 6} \\
\hline & a & $b^{*}$ & C & $d^{*}$ \\
\hline \multicolumn{5}{|l|}{ Ingredients $(\mathrm{g} / \mathrm{kg})$} \\
\hline Yellow maize & $528 \cdot 0$ & $340 \cdot 2$ & $594 \cdot 0$ & $500 \cdot 0$ \\
\hline Sorghum & & $200 \cdot 0$ & & $45 \cdot 7$ \\
\hline Soyabean oil meal & $366 \cdot 0$ & $357 \cdot 0$ & $300 \cdot 0$ & $323 \cdot 0$ \\
\hline Soyabean oil, refined & $30 \cdot 0$ & & $30 \cdot 0$ & \\
\hline Soapstock & & $45 \cdot 0$ & & $55 \cdot 0$ \\
\hline Fish meal & & $10 \cdot 0$ & & \\
\hline $\mathrm{NaCl}$ & $3 \cdot 0$ & $3 \cdot 0$ & $3 \cdot 0$ & $3 \cdot 0$ \\
\hline DL-methionine & 1.94 & $2 \cdot 0$ & $2 \cdot 0$ & $2 \cdot 0$ \\
\hline Vitamin mixture & $2 \cdot 5$ & 2.5 & 2.5 & 2.5 \\
\hline Trace mineral mixture $\ddagger$ & 0.3 & 0.3 & 0.3 & 0.3 \\
\hline $\mathrm{KH}_{2} \mathrm{POD}_{4}+\mathrm{NaH}_{2} \mathrm{PO}_{4} \cdot \mathrm{H}_{2} \mathrm{O}(1: 1)$ & Varied & $8 \cdot 0$ & 0 & $8 \cdot 0$ \\
\hline $\mathrm{CaHPO}_{4} \cdot 2 \mathrm{H}_{2} \mathrm{O}$ (commercial grade) & Varied & 7.5 & Varied & 7.5 \\
\hline Ground limestone & Varied & Varied & Varied & Varied \\
\hline \multicolumn{5}{|l|}{ Calculated composition } \\
\hline Metabolizable energy (mJ/kg) & $12 \cdot 1$ & $12 \cdot 5$ & $12 \cdot 3$ & $12 \cdot 9$ \\
\hline Crude protein & 208 & 211 & 184 & 190 \\
\hline $\mathrm{Ca}$ & $1 \cdot 2$ & $1 \cdot 3$ & 1.0 & $1 \cdot 1$ \\
\hline Total P & 3.9 & $7 \cdot 2$ & 3.6 & $6 \cdot 8$ \\
\hline Available P & 1.3 & 4.5 & $1 \cdot 2$ & 4.3 \\
\hline
\end{tabular}

* Experiment 5 only.

†The vitamin mixture supplied (/ $\mathrm{kg}$ feed): retinyl acetate $2.9 \mathrm{mg}$ ( $8400 \mathrm{lU})$; cholecalciferol, $50 \mu \mathrm{g}$ (2000 IU); $\alpha$-tocopheryl acetate, $24 \mathrm{mg}$; menadione, $2 \mathrm{mg}$; riboflavin, $5.6 \mathrm{mg}$; Ca-pantothenate, $11.2 \mathrm{mg}$; thiamine, $0.8 \mathrm{mg}$; niacin, $29.6 \mathrm{mg}$; vitamin $\mathrm{B}_{12}, 0.008 \mathrm{mg}$; folic acid, $0.8 \mathrm{mg}$; pyridoxine, $2.4 \mathrm{mg}$; biotin, $0.1 \mathrm{mg}$, choline chloride, $200 \mathrm{mg}$; manox (antioxidant), $125 \mathrm{mg}$.

‡The mineral mix supplied (mg/kg feed): Mn, 80; Zn, 50; Fe, 25; Cu, 2; I, 1.2; Co, 0.2; Se, 0.1. 
body weight (BW) and variance. This procedure was followed within each age and sex. In experiments 5 to 7 , each diet was fed for 7 or $14 \mathrm{~d}$ to four or six replicate groups of ten or five birds aged 8-21 or 29-43 d, respectively. The experimental diets were designed to satisfy the NRC recommendations (National Research Council, 1994). The basal ingredients of the diets are given in Table 1; the designed experimental diets varied in their $\mathrm{Ca}$ and $\mathrm{P}$ contents, through the addition of various amounts of ground limestone, $\mathrm{CaHPO}_{4} \cdot 2 \mathrm{H}_{2} \mathrm{O}$ and $\mathrm{NaH}_{2} \mathrm{PO}_{4} \cdot \mathrm{H}_{2}$ $\mathrm{O}+\mathrm{KH}_{2} \mathrm{PO}_{4}$ to the basal ingredients. When $\mathrm{NaH}_{2} \mathrm{PO}_{4} \cdot \mathrm{H}_{2}$ $\mathrm{O}+\mathrm{KH}_{2} \mathrm{PO}_{4}$ was used, $\mathrm{NaHCO}_{3}$ and $\mathrm{KHCO}_{3}$ were added to keep the $\mathrm{Na}$ and $\mathrm{K}$ contents constant. The dietary $\mathrm{Ca}$ and $\mathrm{P}$ contents presented in the text, figures. and Tables 2 to 6 are always those obtained by chemical analysis.

During the experiments, BW and feed intake were determined weekly on individual and group bases, respectively. At the end of experiments 1 to 4, blood samples were obtained by cardiac puncture, with heparin used as an anticoagulant. Birds were killed by neck dislocation and sampled for the determination of duodenal calbindin, bone ash and renal 1-hydroxylase activity. At the end of experiments 5 to 7 , the eight birds with $\mathrm{BW}$ closest to the average were removed from each treatment group for bone analysis. They were killed by neck dislocation, and the tibiae were removed for bone ash determination. The experimental protocols were approved by the National Committee for Animal Experimentation Ethics, and were conducted according to the Israeli Law on Animal Welfare and Experimentation, 1994.

Three series of experiments were conducted in order: (a) to evaluate the effects of dietary $\mathrm{Ca}$ and $\mathrm{P}$ on cholecalciferol metabolism and expression (experiments 1 to 4); (b) to determine dietary $\mathrm{Ca}$ requirements in 29 - to 43-d-old chickens (experiment 5); (c) to determine dietary $\mathrm{P}$ requirements in fast-growing chickens (experiments 6 and 7).

\section{Experiment 1}

The purpose of experiment 1 was to evaluate the effects of restriction or excess of dietary $\mathrm{Ca}, \mathrm{P}$ or both, on plasma $\mathrm{Ca}$ and inorganic $\mathrm{P}$, on bone ash, and on the metabolism and expression of cholecalciferol, in young fast-growing chicks. The experimental diets were fed for $11 \mathrm{~d}$ to ten 1-d-old chicks. At the end of the experiment, six to eight birds were bled and sampled for the determination of bone ash, and for calbindin and 1-hydroxylase analyses.

\section{Experiments 2 and 3}

The purpose of these experiments was to determine the effects of age on plasma $\mathrm{Ca}$, inorganic $\mathrm{P}$, duodenal calbindin, and bone ash. Day-old chicks were fed standard commercial diets, designed to satisfy the NRC recommendations (National Research Council, 1994). Seven birds were bled and sampled for duodenal calbindin and bone ash at each of the ages of 8, 15, 22, 29 and $43 \mathrm{~d}$. Experiments 2 and 3 were conducted in 1991 and 2001, respectively.

\section{Experiment 4}

The purpose of experiment 4 was to compare the effects of dietary $\mathrm{Ca}$ or $\mathrm{P}$ restriction on plasma $\mathrm{Ca}$ and inorganic $\mathrm{P}$, duodenal calbindin and bone ash, in 22- or 43-d-old chicks. The experimental diets were fed to ten chicks for $7 \mathrm{~d}$. The diets supplied the chicks with 10.5 or $5.5 \mathrm{~g} \mathrm{Ca} /$ $\mathrm{kg}$ diet and 7.5 or $4.4 \mathrm{~g}$ total $\mathrm{P} / \mathrm{kg}$ diet. At the end of the experiment, eight birds were bled and sampled.

\section{Experiment 5}

The purpose of experiment 5 was to evaluate the effects of age on the requirements for $\mathrm{Ca}$. The experimental diets were fed for $7 \mathrm{~d}$ to 8 - or 15 -d-old chicks, and for $14 \mathrm{~d}$ to 29-d-old chicks. The diets for the 8- to 22-d-old and the 29- to 43-d-old chicks contained 7.2 and $6.9 \mathrm{~g} \mathrm{P} / \mathrm{kg}$ diet, respectively. The basal diets used were $b$ and $d$ (Table 1). Bone ash was determined at the ages of 15,22 and $43 \mathrm{~d}$.

\section{Experiment 6}

The purpose of experiment 6 was to evaluate the effects of age and sex on the requirements for $\mathrm{P}$. The experimental diets were fed for $14 \mathrm{~d}$ to 8 - or 29-d-old chicks, and contained $10.5 \mathrm{~g} \mathrm{Ca} / \mathrm{kg}$ diet.

\section{Experiment 7}

The purpose of experiment 7 was to evaluate the effects of dietary $\mathrm{Ca}$ on the $\mathrm{P}$ requirements of 29 - to 43 -d-old fastgrowing chickens.

\section{Chemical analysis}

Bones were cleaned of any adhering tissues, dried at $105^{\circ} \mathrm{C}$ and ashed at $650^{\circ} \mathrm{C}$ for $4 \mathrm{~h}$. Blood samples were centrifuged and plasma was harvested. Plasma $\mathrm{Ca}$ was determined in $\mathrm{HNO}_{3}$-digested samples by means of an Atomic Emission Spectrometer (Spectro, Germany), or directly by automatic titration (Bar \& Hurwitz, 1981; experiment 1). Inorganic $P$ was determined in supernatant fractions of TCA-treated plasma, with an Atomic Emission Spectrometer or colorimetrically according to Gomori (1942) (experiment 1).

Renal 1-hydroxylase activity was determined as described previously (Montecuccoli et al. 1977). Duodenal calbindin was determined with a radioimmunoassay (Bar \& Hurwitz, 1979) (experiments 1 and 2) or by means of a newly developed specific ELISA (S Yosefi and A Bar, unpublished results; experiments 3 and 4 ).

\section{Numerical analysis}

The results were analysed routinely by ANOVA (Snedecor \& Cochran, 1967), and differences between means were tested by Duncan's multiple range test (Duncan, 1955). Statistical tests were performed on replicate averages for growth and feed efficiency data, to account for the effects of location, whereas individual values were used for the chemical assays. 
For calculation of the $\mathrm{Ca}$ or $\mathrm{P}$ requirements, the results of BW gain and tibia ash determinations were fitted to a quadratic equation (Hurwitz et al. 1995). The coefficients of determination $\left(R^{2}\right)$ served as measures of goodness of fit. Values given in Tables are based on the analysed dietary contents, together with values based on the calculated dietary content.

\section{Results \\ Experiment 1}

The results of experiment 1 (Table 2) show that dietary $\mathrm{Ca}$ restriction caused slight hypocalcaemia, increased the kidney 1-hydroxylase and duodenal calbindin and decreased bone ash. Dietary P restriction caused hypercalcaemia and hypophosphataemia, increased duodenal calbindin but not kidney 1-hydroxylase, and markedly reduced bone ash. The hypercalcaemia and hypophosphataemia observed in the dietary P-restricted birds were ameliorated by reducing the dietary Ca level from 10.4 to $1.9 \mathrm{~g} /$ $\mathrm{kg}$ diet; however, the duodenal calbindin remained as high and the bone ash as low as in the P-restricted birds fed $10.3 \mathrm{~g} \mathrm{Ca} / \mathrm{kg}$ diet. Hypercalcaemia and hypophosphataemia were observed also when the dietary $\mathrm{Ca}$ was increased from 10.4 to $21.6 \mathrm{~g} / \mathrm{kg}$ diet. The reductions in duodenal calbindin and in bone ash in chicks fed the high dietary $\mathrm{Ca}$ were ameliorated by raising the dietary $\mathrm{P}$ level from 7.2 to $10.7 \mathrm{~g} / \mathrm{kg}$ diet. The dietary combination of high $\mathrm{Ca}$ and high $\mathrm{P}$ resulted in the highest bone ash content.

\section{Experiments 2 and 3}

Duodenal calbindin (Fig. 1) decreased progressively in experiment 2 (conducted in 1991), but in experiment 3 (conducted in 2001) it increased slightly up to the 29th day, and then decreased slightly. The effects on duodenal calbindin in both experiments were significant $(P<0 \cdot 05)$. Bone ash increased progressively in both experiments, but its values were higher in experiment 3 (conducted in 2001). In experiment 3 the tibia ash:BW ratio tended to increase with age.

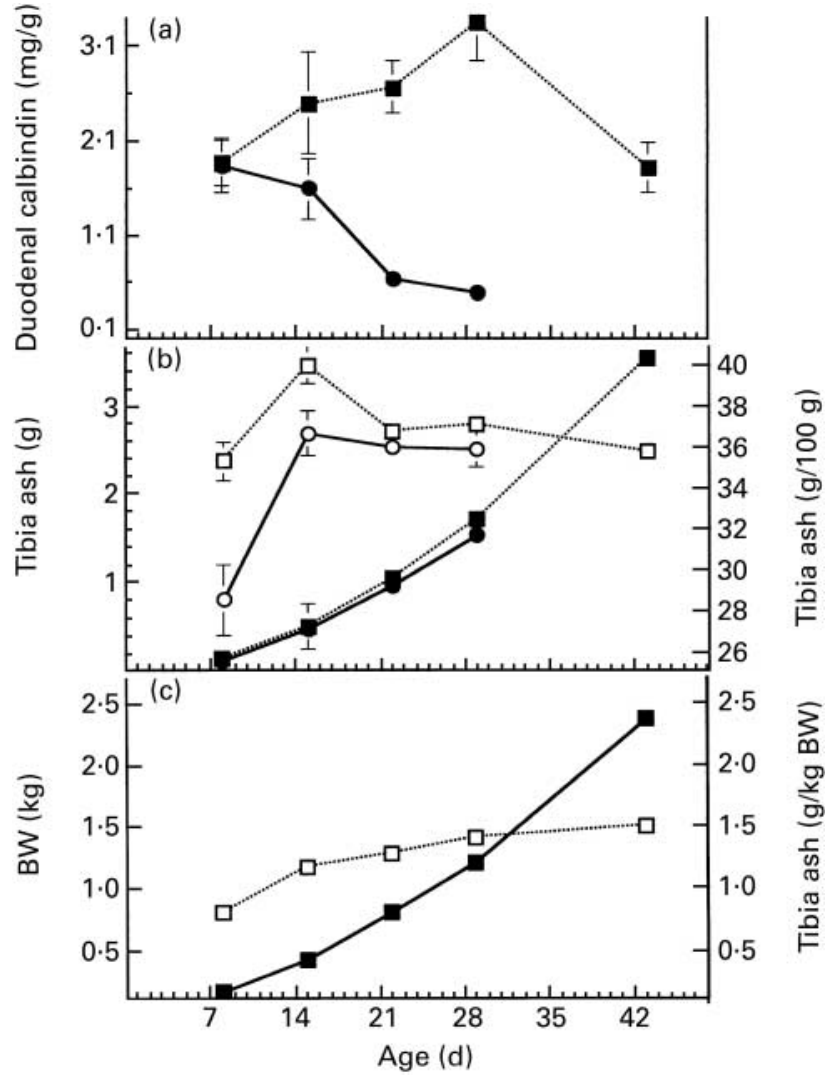

Fig. 1. (a), Duodenal calbindin; (b), tibia ash $(\bigcirc$ and $\square, \mathrm{g} / 100 \mathrm{~g}$;

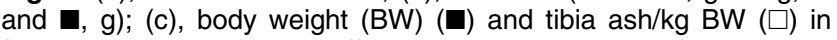
fast-growing chickens, as affected by age and year of experiment ( $\bigcirc$ and ๑, 1991 (experiment 2); $\square$ and $\mathbf{\square}, 2001$ (experiment 3). Mean values are shown, with standard errors of difference represented by vertical bars.

\section{Experiment 4}

Results of experiment 4 (Table 3) indicate that with increasing age, bone ash weight increased significantly (not given in the Table), but its percentage $(\mathrm{g} / 100 \mathrm{~g}$ ) decreased significantly. Dietary $\mathrm{Ca}$ or $\mathrm{P}$ restriction

Table 2. The effects of dietary calcium and phosphorus on plasma concentrations of total calcium and inorganic phosphorus $\left(P_{i}\right)$, duodenal calbindin, renal 25 hydoxycholecalciferol-1-hydroxylase (1-hydroxylase), and tibia ash of 12-d-old chicks fed the experimental diets for 11d (experiment 1$)^{*}$

(Means values with their standard errors of the difference for six to eight birds)

\begin{tabular}{|c|c|c|c|c|c|c|c|c|c|c|c|}
\hline \multirow{2}{*}{\multicolumn{2}{|c|}{$\begin{array}{l}\text { Dietary level } \\
(\mathrm{g} / \mathrm{kg})\end{array}$}} & \multicolumn{4}{|c|}{ Plasma concentration (nmole/l) } & \multirow{2}{*}{\multicolumn{2}{|c|}{$\begin{array}{c}\text { Duodenal } \\
\text { calbindin }(\mathrm{mg} / \mathrm{g})\end{array}$}} & \multirow{2}{*}{\multicolumn{2}{|c|}{$\begin{array}{c}\text { Renal } \\
\text { 1-hydroxylase } \\
\text { (pmole/g per min) }\end{array}$}} & \multirow{2}{*}{\multicolumn{2}{|c|}{$\begin{array}{l}\text { Tibia ash } \\
(\mathrm{g} / 100 \mathrm{~g})\end{array}$}} \\
\hline & & \multicolumn{2}{|c|}{$\mathrm{Ca}$} & \multicolumn{2}{|c|}{$P_{i}$} & & & & & & \\
\hline 1.9 & 3.9 & $2 \cdot 13^{c}$ & 0.10 & $2 \cdot 07^{\mathrm{ab}}$ & 0.23 & $2.03^{a}$ & 0.10 & $1.77^{\mathrm{b}}$ & 0.19 & $21 \cdot 6^{d}$ & $1 \cdot 2$ \\
\hline 1.9 & $7 \cdot 2$ & $2 \cdot 35^{\mathrm{bc}}$ & 0.10 & $2 \cdot 50^{\mathrm{a}}$ & 0.17 & $1.90^{\mathrm{a}}$ & 0.11 & $3 \cdot 25^{\mathrm{a}}$ & 0.51 & $27 \cdot 6^{\mathrm{c}}$ & 0.5 \\
\hline $10 \cdot 3$ & 3.9 & $3 \cdot 30^{a}$ & 0.18 & $0.53^{c}$ & 0.10 & $1.59^{b}$ & 0.22 & $1.55^{\mathrm{bc}}$ & 0.25 & $18 \cdot 4^{\mathrm{d}}$ & 1.0 \\
\hline $21 \cdot 6$ & $7 \cdot \overline{1}$ & $3.55^{a}$ & 0.23 & $0.90^{c}$ & 0.17 & $0.48^{d}$ & 0.10 & $0 \cdot 71^{b c}$ & 0.13 & $31 \cdot 3^{b}$ & 0.9 \\
\hline $10 \cdot 1$ & $11 \cdot 1$ & $2 \cdot 68^{b}$ & 0.13 & $1.87^{b}$ & 0.13 & $1.04^{\mathrm{C}}$ & 0.06 & $1.53^{b c}$ & 0.28 & $37 \cdot 5^{\mathrm{ab}}$ & 0.7 \\
\hline $21 \cdot 8$ & $10 \cdot 7$ & $2 \cdot 73^{b}$ & 0.10 & $2 \cdot 30^{\mathrm{ab}}$ & 0.13 & $0.71^{\mathrm{cd}}$ & 0.04 & $0.58^{\mathrm{C}}$ & 0.07 & $40 \cdot 2^{a}$ & $1 \cdot 0$ \\
\hline
\end{tabular}

a,b,c,d Mean values within a column with unlike superscript letters were significantly different $(P<0.05)$ by Duncan's test.

${ }^{*}$ For details of diets and procedures, see Table 1 and p. 53. 

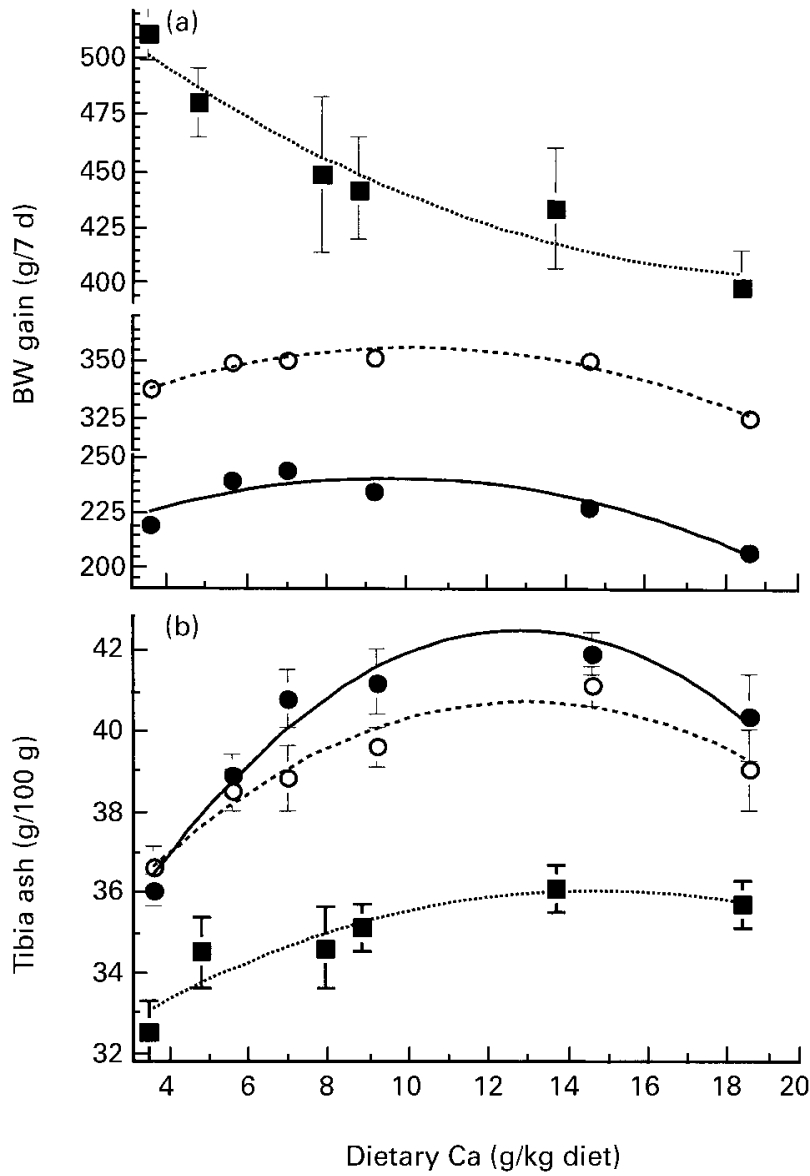

Fig. 2. (a), Body weight (BW) gain (during the last $7 \mathrm{~d}$ ); (b), tibia ash in fast-growing chickens as affected by age and dietary calcium ( $n 4$ or 6 replicates and $n 8$ individuals for weight gain and tibia ash, respectively) in experiment 5 . (๑), $15 \mathrm{~d}$ old; $(O), 22 \mathrm{~d}$ old; $(\boldsymbol{\square}), 43 \mathrm{~d}$ old. Mean values are shown, with standard errors of difference represented by vertical bars.

significantly induced the formation of duodenal calbindin and decreased bone ash; the effect of dietary $\mathrm{P}$ restriction was more pronounced. Dietary $\mathrm{P}$ restriction significantly increased plasma $\mathrm{Ca}$ and decreased plasma inorganic $\mathrm{P}$; the effect on plasma $\mathrm{Ca}$ was more pronounced in the 22-d-old chicks (significant interaction). BW (not given in Table 3) was higher in the 43-d-old chicks but was not affected significantly by dietary $\mathrm{Ca}$ or $\mathrm{P}$.

\section{Experiment 5}

When the responses of $\mathrm{Ca}$ requirements to age were studied, the effects of dietary $\mathrm{Ca}$ and age were significant $(P<0.05)$ for all response criteria. A bell-shaped (Fig. 2) response of tibia ash to dietary $\mathrm{Ca}$ level was observed. A similar response of $\mathrm{BW}$ gain to dietary $\mathrm{Ca}$ level was also observed in 8- to 15-, and 15- to 22-d-old chickens (Fig. 2). In contrast, weight gain in 36- to 43-d-old chickens was progressively reduced as dietary $\mathrm{Ca}$ increased, indicating a significant $\mathrm{Ca} \times$ age interaction. The results of experiment 5 (Table 4) show that the optimal $\mathrm{Ca}$ requirements for bone calcification were higher than those for BW gain in 8- to 22-d-old chickens. A similarly

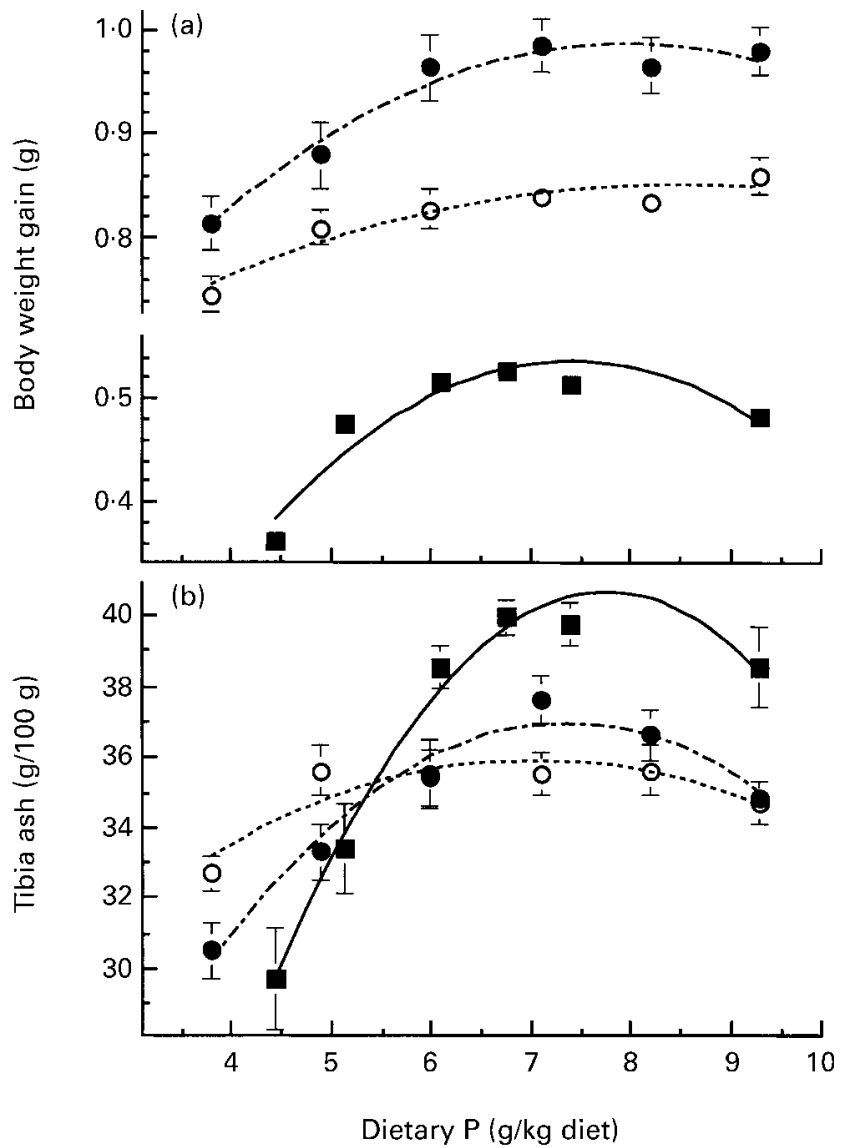

Fig. 3. (a), Body weight gain; (b), tibia ash in 8- to 22-d-old fastgrowing chickens, as affected by age and sex, and dietary total phosphorus ( $n 6$ replicates and $n 8$ individuals for weight gain and

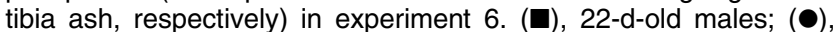
43-d-old males; $(\bigcirc)$, 43-d-old females. Mean values are shown, with standard errors of difference represented by vertical bars.

high calculated $\mathrm{Ca}$ requirement for bone ash was observed in 29- to 43-d-old chickens, although the ash content and its sensitivity to dietary $\mathrm{Ca}$ were less.

\section{Experiment 6}

In experiment 6 the $\mathrm{P}$ requirements of 8 - to 22-d-old male and 29- to 43-d-old male and female fast-growing chicks were determined. The results are shown in Fig. 3. The effects of $\mathrm{P}$, age and sex on BW gain, and the effects of $P$ and age on bone ash were significant (not given in detail). Bell-shaped responses of $\mathrm{BW}$ gain and tibia ash to dietary $\mathrm{P}$ level were observed in male chickens. A similar bell-shaped response of bone ash was observed in the female chicks, whereas the response of the BW gain of the female chickens tended to reach a plateau, and not a clear maximum. Quadratic equations were used to calculate the optimal $\mathrm{P}$ requirements. The results of experiment 6 (Table 5) show that, except for BW gain in the 22- to 43d-old female chicks, $P$ requirements for optimal bone calcification and BW gain at both ages were quite similar. 
Table 3. The effects of dietary calcium or phosphorus restriction and age on plasma concentrations of total $\mathrm{Ca}$ and inorganic phosphorus $\left(\mathrm{P}_{\mathrm{i}}\right)$, duodenal calbindin and tibia ash of chicks fed the experimental diets for $7 \mathrm{~d}$ (experiment 4$)^{\star}$

(Means values and standard errors of the means for six to eight birds in each experimental group)

\begin{tabular}{|c|c|c|c|c|c|c|c|}
\hline \multirow[b]{2}{*}{ Age (d) } & \multicolumn{2}{|c|}{$\begin{array}{l}\text { Dietary level } \\
\quad(\mathrm{g} / \mathrm{kg})\end{array}$} & \multicolumn{2}{|c|}{$\begin{array}{l}\text { Plasma concentration } \\
\text { (nmole/l) }\end{array}$} & \multirow{2}{*}{$\begin{array}{l}\text { Duodenal } \\
\text { calbindin } \\
\text { (mg/g) }\end{array}$} & \multicolumn{2}{|c|}{ Tibia ash } \\
\hline & $\mathrm{Ca}$ & $P$ & $\mathrm{Ca}$ & $\mathrm{P}_{\mathrm{i}}$ & & $g$ & $g / 100 \mathrm{~g}$ \\
\hline 22 & & & $3 \cdot 28$ & 1.73 & 2.95 & $0.913^{a}$ & $36 \cdot 5^{a}$ \\
\hline 43 & & & 3.11 & 1.82 & 2.72 & $3 \cdot 183^{b}$ & $33 \cdot 8^{\mathrm{b}}$ \\
\hline \multirow[t]{4}{*}{ SEM } & & & 0.08 & 0.11 & 0.23 & 0.045 & 0.4 \\
\hline & $10 \cdot 5$ & 7.5 & $2 \cdot 96^{\mathrm{b}}$ & $2.09^{a}$ & $1.64^{\mathrm{b}}$ & $2 \cdot 336^{a}$ & $37.9^{\mathrm{a}}$ \\
\hline & 5.5 & 7.5 & $2 \cdot 78^{\mathrm{b}}$ & $2 \cdot 17^{\mathrm{a}}$ & $3 \cdot 18^{\mathrm{a}}$ & $2.025^{\mathrm{b}}$ & $36 \cdot 4^{\mathrm{a}}$ \\
\hline & 10.5 & 4.4 & $3.86^{\mathrm{a}}$ & $1.08^{\mathrm{b}}$ & $3.83^{\mathrm{a}}$ & $1.742^{\mathrm{c}}$ & $31.2^{b}$ \\
\hline SEM & & & 0.10 & 0.13 & 0.29 & 0.055 & $0 . \overline{5}$ \\
\hline 22 & 10.5 & 7.5 & $2.98^{\mathrm{C}}$ & & & & $40 \cdot 0^{\mathrm{a}}$ \\
\hline 22 & 5.5 & 7.5 & $2.69^{\mathrm{C}}$ & & & & $38 \cdot 4^{\mathrm{a}}$ \\
\hline 22 & 10.5 & 4.4 & $4 \cdot 18^{a}$ & & & & $31 \cdot 2^{\mathrm{C}}$ \\
\hline 42 & 10.5 & 7.5 & $2.94^{\mathrm{C}}$ & & & & $35 \cdot 8^{b}$ \\
\hline 42 & 5.5 & 7.5 & $2 \cdot 86^{\mathrm{C}}$ & & & & $34.4^{\mathrm{b}}$ \\
\hline 42 & 10.5 & 4.4 & $3.53^{\mathrm{b}}$ & & & & $31 \cdot 2^{\mathrm{c}}$ \\
\hline SEM & & & 0.14 & & & & $0 . \overline{7}$ \\
\hline \multicolumn{8}{|l|}{ Probability } \\
\hline Age & & & 0.141 & 0.249 & 0.688 & $<0.001$ & $<0.001$ \\
\hline Diet & & & $<0.001$ & $<0.001$ & $<0.001$ & $<0.001$ & $<0.001$ \\
\hline Age $x$ diet & & & 0.020 & 0.592 & 0.472 & 0.314 & 0.009 \\
\hline
\end{tabular}

${ }^{a, b, c}$ Mean values within a column for each variable with unlike superscript letters were significantly different $(P<0.05)$ by Duncan's test.

${ }^{*}$ For details of diets and procedures, see Table 1 and p. 53.

\section{Experiment 7}

When the influence of dietary $\mathrm{Ca}$ on $\mathrm{P}$ requirements was studied in 29- to 43-d-old chickens, the effects of dietary $\mathrm{P}$ (Table 6), but not those of $\mathrm{Ca}$, were significant for all response criteria. $\mathrm{Ca} \times \mathrm{P}$ interactions were significant for BW gain and tibia ash (Fig. 4). These interactions most probably resulted from the slightly higher BW of chickens fed $10.4 \mathrm{~g} \mathrm{Ca} / \mathrm{kg}$ diet and the two higher dietary $\mathrm{P}$ levels, and from the remarkable effect of dietary $\mathrm{Ca}$ on bone ash of chicks fed 6.2 to $8.5 \mathrm{~g}$ total dietary $\mathrm{P} / \mathrm{kg}$ diet, whereas at the lowest $\mathrm{P}$ intake the higher dietary $\mathrm{Ca}$ content markedly reduced the $\mathrm{BW}$ and bone ash. Quadratic equations were used to calculate the optimal $\mathrm{P}$ requirements for BW gain and tibia ash. The values given in Table 5 indicate that the optimal $\mathrm{P}$ levels for $\mathrm{BW}$ gain and for bone ash are quite similar.

\section{Discussion}

As previously shown (Hurwitz et al. 1995) and confirmed later (Williams et al. 2000), the $\mathrm{Ca}$ requirement for growth of the young (7- to 21-d-old) fast-growing chicken fed the recommended dietary $\mathrm{P}$ level is similar to, or even slightly higher than, the National Research Council (1994) recommendation. However, the Ca requirement for optimal bone ash is markedly higher than the recommended level (Table 4). Unlike $\mathrm{Ca}$, we found the $\mathrm{P}$ requirements for growth and bone ash of the young fast-growing chicken to be similar (Table 5). Our estimated $\mathrm{P}$ requirement is slightly higher $(7.4-7.8 \mathrm{~g} \mathrm{P} / \mathrm{kg}$ or $4.8-5.2 \mathrm{~g}$ non-phytate $\mathrm{P} / \mathrm{kg}$ diet) than the NRC recommendation or than the estimates of Rao \& Reddy (1999) or Waldroup et al. (2000), but are quite similar to the findings of Mitchell \& Edwards (1996).
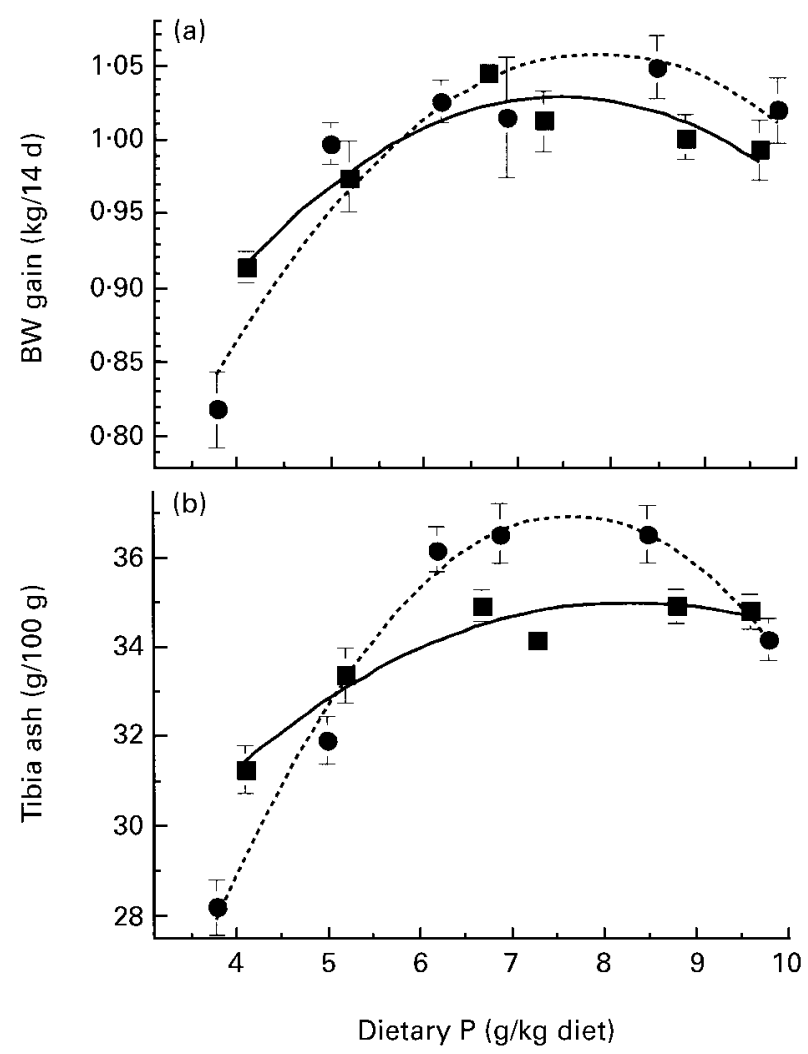

Fig. 4. (a), Body weight (BW) gain; (b), tibia ash in fast-growing Cobb chickens as affected by dietary calcium and phosphorus ( $n 6$ replicates and $n 8$ individuals for weight gain and tibia ash, respectively) in experiment 7. (目, $8.1 \mathrm{~g} \mathrm{Ca} / \mathrm{kg}$ diet; $(\bullet), 10.4 \mathrm{~g} \mathrm{Ca} / \mathrm{kg}$ diet. Mean values are shown, with standard errors of difference represented by vertical bars. 
Table 4. Coefficient of determination $\left(R^{2}\right)$ for fitting quadratic equation, analysed and estimated calcium requirements as influenced by age and dietary total phosphorus in fast-growing chickens (experiment 5$)^{\star}$

\begin{tabular}{|c|c|c|c|c|c|c|c|}
\hline \multirow[b]{3}{*}{ Age $(d) \dagger$} & \multirow{3}{*}{$\begin{array}{l}\text { Dietary P } \\
(\mathrm{g} / \mathrm{kg}) \ddagger\end{array}$} & \multicolumn{3}{|c|}{ Weight gain $(\mathrm{kg} / 7 \mathrm{~d})$} & \multicolumn{3}{|c|}{ Tibia ash $(\mathrm{g} / 100 \mathrm{~g})$} \\
\hline & & \multirow[b]{2}{*}{$R^{2}$} & \multicolumn{2}{|c|}{$\begin{array}{l}\text { Ca requirement } \\
\text { (g/kg diet) }\end{array}$} & \multirow[b]{2}{*}{$R^{2}$} & \multicolumn{2}{|c|}{$\begin{array}{l}\text { Ca requirement } \\
\text { (g/kg diet) }\end{array}$} \\
\hline & & & Analysed $\ddagger$ & Estimated $\S$ & & Analysed & Estimated§ \\
\hline $8-14$ & $7 \cdot 2$ & 0.824 & 9.6 & 9.9 & 0.955 & $12 \cdot 8$ & 13.9 \\
\hline $15-21$ & $7 \cdot 2$ & 0.951 & 10.9 & $10 \cdot 4$ & 0.937 & $13 \cdot 0$ & $14 \cdot 0$ \\
\hline $36-43$ & 6.9 & 0.932 & NC & & 0.867 & $14 \cdot 7$ & $15 \cdot 7$ \\
\hline
\end{tabular}

NC, not calculated (because the plot was convex rather than concave).

${ }^{*}$ For details of diets and procedures, see Table 1 and p. 53

† Experimental diets were fed from the age of 29 until $43 \mathrm{~d}$.

$\ddagger$ By chemical analysis. The calculated $\mathrm{P}$ contents are given in Table 1.

$\S$ The estimated $\mathrm{Ca}$ requirements are based on the calculated dietary Ca content.

Table 5. Coefficient of determination $\left(R^{2}\right)$ for fitting quadratic equation, analysed and estimated phosphorus requirements and source of variation in fast-growing chickens as influenced by age, breed, sex and dietary calcium*

\begin{tabular}{|c|c|c|c|c|c|c|c|c|}
\hline \multirow[b]{3}{*}{ Sex } & \multirow[b]{3}{*}{ Age (d) } & \multirow[b]{3}{*}{ Dietary Ca $(\mathrm{g} / \mathrm{kg}) \dagger$} & \multicolumn{3}{|c|}{ Weight gain (kg) } & \multicolumn{3}{|c|}{ Tibia ash (g/100 g) } \\
\hline & & & \multirow[b]{2}{*}{$R^{2}$} & \multicolumn{2}{|c|}{$P$ requirement ( $\mathrm{g} / \mathrm{kg}$ diet) } & \multirow[b]{2}{*}{$R^{2}$} & \multicolumn{2}{|c|}{$P$ requirement (g/kg diet) } \\
\hline & & & & Analysed $†$ & Estimatedł & & Analysed $†$ & Estimatedł \\
\hline \multicolumn{9}{|c|}{ Experiment 6} \\
\hline Male & $8-21$ & $10 \cdot 4$ & 0.900 & $7 \cdot 4$ & 8.0 & 0.984 & $7 \cdot 8$ & 8.9 \\
\hline Male & $29-43$ & 10.5 & 0.959 & $8 \cdot 0$ & $8 \cdot 0$ & 0.970 & $7 \cdot 4$ & 7.4 \\
\hline Female & $29-43$ & 10.5 & 0.814 & 8.5 & $8 \cdot 6$ & 0.788 & $7 \cdot 0$ & $7 \cdot 2$ \\
\hline \multicolumn{9}{|c|}{ Experiment 7} \\
\hline Male & $29-43$ & $8 \cdot 1$ & 0.990 & $7 \cdot 4$ & $7 \cdot 1$ & 0.929 & 7.9 & 7.9 \\
\hline Male & $29-43$ & $10 \cdot 2$ & 0.955 & 7.9 & $7 \cdot 5$ & 0.984 & $7 \cdot 7$ & $7 \cdot 4$ \\
\hline
\end{tabular}

${ }^{*}$ For details of diets and procedures, see Table 1 and p. 53.

† By chemical analyses. Calculated Ca contents of the diets were 11 and 10 or $8 \mathrm{~g} \mathrm{Ca} / \mathrm{kg}$ for the 8-21- and 29-43-d-old chicks.

$\ddagger$ The estimated requirements are based on the calculated dietary $\mathrm{P}$ content.

Table 6. Major effects of dietary total phosphorus and calcium on body weight (BW), BW gain, feed efficiency and tibia ash in 29- to 43-d-old fast-growing Cobb chickens (experiment 6)*

(Means values and standard errors of the means)

\begin{tabular}{|c|c|c|c|c|c|}
\hline Dietary Ca $(\mathrm{g} / \mathrm{kg})$ & Dietary P (g/kg) & BW (kg)† & BW gain $(\mathrm{kg} / 2$ weeks) & Feed efficiency $\dagger$ & Tibia ash $(\mathrm{g} / 100 \mathrm{~g}) \ddagger$ \\
\hline $8 \cdot 1$ & & $2 \cdot 165$ & 0.990 & 0.468 & 33.9 \\
\hline 1.04 & & $2 \cdot 173$ & 0.985 & 0.462 & 33.9 \\
\hline \multirow{7}{*}{ SEM } & & 0.009 & 0.008 & 0.005 & 0.4 \\
\hline & 3.9 & $2 \cdot 054^{\mathrm{b}}$ & $0.883^{c}$ & $0.423^{b}$ & $29 \cdot 7^{\mathrm{C}}$ \\
\hline & 5.1 & $2 \cdot 165^{a}$ & $0.985^{\mathrm{b}}$ & $0.466^{\mathrm{a}}$ & $32 \cdot 6^{\mathrm{b}}$ \\
\hline & $6 \cdot 4$ & $2 \cdot 211^{\mathrm{a}}$ & $1.035^{\mathrm{ab}}$ & $0.482^{\mathrm{a}}$ & $35 \cdot 5^{\mathrm{a}}$ \\
\hline & $7 \cdot 1$ & $2 \cdot 185^{a}$ & $1.011^{\mathrm{ab}}$ & $0.473^{\mathrm{a}}$ & $35 \cdot 3^{\mathrm{a}}$ \\
\hline & 8.6 & $2 \cdot 201^{a}$ & $1.024^{\mathrm{ab}}$ & $0.482^{\mathrm{a}}$ & $35 \cdot 7^{\mathrm{a}}$ \\
\hline & 9.7 & $2 \cdot 182^{\mathrm{a}}$ & $1.006^{\mathrm{ab}}$ & $0.476^{\mathrm{a}}$ & $34.4^{\mathrm{a}}$ \\
\hline SEM & & 0.017 & 0.013 & 0.009 & 0.4 \\
\hline \multicolumn{6}{|l|}{ Probability } \\
\hline $\mathrm{Ca}$ & & 0.882 & 0.602 & 0.518 & 0.989 \\
\hline $\mathrm{P}$ & & $<0.001$ & $<0.001$ & $<0.001$ & $<0.001$ \\
\hline $\mathrm{Ca} \times \mathrm{P}$ & & 0.123 & 0.025 & 0.383 & $<0.001$ \\
\hline
\end{tabular}

a,b,c Mean values within a column for each variable with unlike superscript letters were significantly different $(P<0.05)$ by Duncan's test.

${ }^{*}$ For details of diets and procedures, see Table 1 and p. 53.

† Means of six replicates of five birds.

$\ddagger$ Means of eight birds. 
The fast-growing young chicken adapts itself to dietary $\mathrm{Ca}$ or $\mathrm{P}$ restriction by increasing intestinal $\mathrm{Ca}$ and $\mathrm{P}$ absorption (Morrissey \& Wasserman, 1971; Montecuccoli et al. 1977), most probably as a result of the elevation in plasma and intestinal concentrations of $1,25(\mathrm{OH})_{2} \mathrm{D}_{3}$ (Bar et al. 1982; Hunziker et al. 1982), and duodenal calbindin (Tables 2 and 3; Morrissey \& Wasserman, 1971; Montecuccoli et al. 1977), although the kidney 1-hydroxylase concentration has been shown to be increased only by dietary Ca restriction (Table 2; Friedlander et al. 1977; Montecuccoli et al. 1977). However, the increased absorption cannot compensate for the low intake under severe restriction (Bar et al. 1979); therefore, bone ash markedly declines. Table 2 presents, in addition to the well-known responses to dietary $\mathrm{Ca}$ or $\mathrm{P}$ restriction, the responses of the young chick to excess of dietary $\mathrm{Ca}$ or $\mathrm{P}$ and to restriction or excess of both of these two minerals in combination. Such a combined restriction of $\mathrm{Ca}$ and $\mathrm{P}$ may prevent the hypophosphataemia and hypercalcaemia caused by dietary $\mathrm{P}$ restriction, but cannot prevent the decline in bone mineralization. Intake of excess $\mathrm{Ca}$ induced similar effects to those induced by dietary $\mathrm{P}$ restriction, but at the same time led to a reduction, rather than to an elevation, in duodenal calbindin (Table 2; Bar et al. 1990). Excessive Ca and $\mathrm{P}$ intake may prevent these symptoms in birds fed the high-Ca diet and will markedly increase bone ash. The excess of $\mathrm{P}$ alone has no specific effects under normal $\mathrm{Ca}$ intake, except to induce small declines in BW gain and in bone ash (Fig. 4; Hurwitz et al. 1995).

During growth, the needs of minerals for bone formation appeared to be maintained constant or even to increase slightly (Fig. 1). This conclusion is based on the progressive increase in the bone ash:BW ratio, and on the elevation in duodenal calbindin during the first 4 weeks of life (Fig. 1, experiment 3). The duodenal calbindin subsequently decreased slightly and finally reached a similar level to that observed at the age of $8 \mathrm{~d}$. As intestinal calbindin concentration is considered to be a reliable indicator of adaptive capability and of cholecalciferol expression (Bar et al. 1990; Christakos, 1996), the changes in calbindin with age suggest that the normal modern chicken retains the typical accelerated adaptive mechanisms that it developed in its first few days, even at the ages of 29 to $43 \mathrm{~d}$. This was not the case when chicks of the same breed were previously tested, 10 (Fig. 1; Experiment 2) or 20 (Bar \& Hurwitz, 1981) years ago. Then, the adaptive mechanism (as indicated by the duodenal calbindin concentration) rapidly declined. This change in adaptability could be explained by the fact that since 1991 the BW of the 42-d-old male chicken has increased from 2.28 to $3.01 \mathrm{~kg}$ (Israeli Breed Tests, unpublished results), with consequent increases in the body $\mathrm{Ca}$ and $\mathrm{P}$ contents. Therefore, the needs for these elements appeared to have increased.

It is not surprising that the adaptive capability (as indicated by the high calbindin content) of the modern chicken breeds was also retained within the tested range of ages (Table 3). The high age-related adaptability (Fig. 1) observed in the unrestricted 29- to 43-d-old chick can account for the marked elevation in duodenal calbindin observed in the dietary $\mathrm{Ca}$ - or P-restricted chicks in this age range (Table 3 ). Nevertheless, the higher calbindin contents (and most likely the higher rates of $\mathrm{Ca}$ and $\mathrm{P}$ absorption; Bar \& Hurwitz, 1979; Bar et al. 1979) did not prevent the hypercalcaemia, hypophosphataemia and reduction in bone ash (Table 3 ).

Thus, taken together, these findings indicate the need for re-evaluation of the requirements for these minerals in the modern chick, especially in the 28- to 42-d-old one. Although the effects of dietary $\mathrm{P}$ restriction on plasma $\mathrm{Ca}$ and $\mathrm{P}$, and the effect of dietary $\mathrm{Ca}$ or $\mathrm{P}$ restriction on bone ash were less pronounced in the 29- to 43-d-old chickens (Table 3, Fig. 2) than in the younger ones, the curves describing bone ash as a function of dietary $\mathrm{Ca}$ or P still had a bell shape (Figs. 2, 3 and 4). This facilitated the estimation of the $\mathrm{Ca}$ or $\mathrm{P}$ requirements for bone formation in 8- to 22-d-old and in 29- to 43-d-old fast-growing chickens (Tables 4 and 5). As was previously shown (Hurwitz et al. 1995), the Ca requirement for bone ash was markedly higher than the NRC recommendations, especially in the 29- to 43-d-old chickens. On the other hand, increasing the dietary $\mathrm{Ca}$ in 29- to 43-d-old chickens that were fed the recommended $\mathrm{P}$ contents tended to reduce BW progressively (Fig. 2), or hardly to affect it, according to another experiment (A. Bar et al. unpublished results). Thus, a clear determination of the $\mathrm{Ca}$ requirements for growth in 29- to 43-d-old chicks that are fed the recommended $\mathrm{P}$ content was not possible. On the other hand, experiments 6 and 7 clearly demonstrated the significant effects of dietary $\mathrm{P}$ intake on growth, feed efficiency (Table 6) and bone ash. In contrast to our findings on $\mathrm{Ca}$ requirements in the 8 - to 22 -d-old chicken, $\mathrm{P}$ requirements for growth and bone ash (Table 5) were quite similar, and were as high in the older chick as in the young male chicks (7.4-8.0 g P/kg or $4.8-5.6 \mathrm{~g}$ non-phytate $\mathrm{P} / \mathrm{kg} \mathrm{diet).} \mathrm{The}$ average $\mathrm{P}$ requirements for growth and bone ash, as determined in five (not all are presented here) trials conducted with 29- to 43-d-old male chicks fed diets containing 9.6 to $10.5 \mathrm{~g} \mathrm{Ca} / \mathrm{kg}$, were 7.9 (SD 1.0) and 7.5 (SD 0.3) g/kg, respectively. The calculated requirement for growth of the 29 - to 43 -d-old female chick was higher $(8.5 \mathrm{~g} / \mathrm{kg})$, but as only one trial with female chicks was conducted, this value is not necessarily the best or a reliable estimate. On the other hand, the female chick appears to be less sensitive to dietary $\mathrm{P}$ for both growth and bone formation, most likely because of its slower rate of growth (Bar \& Hurwitz, 1981; Hurwitz et al. 1995).

The major effects of sex and age (not given in the Tables) or dietary $\mathrm{Ca}$ (Table 6) on the estimated $\mathrm{P}$ requirements were small or negligible. In experiment 7 , which was conducted in order to determine the effect of dietary $\mathrm{Ca}$ on $\mathrm{P}$ requirements, $\mathrm{Ca}$ did not affect the pooled averages of growth or of tibia ash but, within the total $\mathrm{P}$ range of 6.2 to $8.5 \mathrm{~g} / \mathrm{kg}$ diet $(3.8$ to $6.1 \mathrm{~g}$ available $\mathrm{P} / \mathrm{kg}$ diet; Fig. 4, Table 6; $\mathrm{Ca} \times \mathrm{P}$ significant interactions) a $\mathrm{Ca}$ content of $10.4 \mathrm{~g} / \mathrm{kg}$ diet increased bone ash. BW gain was slightly higher in chicks fed 8.6 to $10.0 \mathrm{~g} \mathrm{P} / \mathrm{kg}$ and $10.4 \mathrm{~g} \mathrm{Ca} / \mathrm{kg}$ diet. Similar results (A. Bar et al. unpublished results) were observed in another trial in which the dietary $\mathrm{Ca}$ contents were 10 and $12 \mathrm{~g} / \mathrm{kg}$ diet). This finding on bone ash is supported by the data presented in Table 1, which indicate that high dietary $\mathrm{P}$ not only prevents the 
hypercalcaemia and hypophosphataemia caused by high dietary $\mathrm{Ca}$, but also ensures highly calcified bones. Therefore, although $\mathrm{Ca}$ appears to be less important in the 29- to 43-d-old chicken than in the younger one, in order that the effect of P be expressed (Fig. 4), diets for 29- to 43-d-old fast-growing chickens should contain 10.0 to $10.5 \mathrm{~g} \mathrm{Ca} / \mathrm{kg}$ diet.

The estimated requirements obtained in the present study should not necessarily be considered as recommendations, as the study was conducted with chicks raised in cages, and used specific sources of inorganic and organic P. However, the data obtained indicate that re-evaluation of $\mathrm{Ca}$ and $\mathrm{P}$ requirements under commercial conditions has become essential. New recommendations should take into account additional factors such as sex differences, prices, the environment and the use of phytases.

\section{Acknowledgements}

A contribution was made from the Agricultural Research Organization, the Volcani Center, Bet Dagan, Israel, no. 404/, 2002 series. This research was supported by grants from the Poultry Marketing Board of Israel.

\section{References}

Armbrecht HJ, Boltz MA, Christakos S \& Bruns MEH (1998) Capacity of 1,25-dihydroxyvitamin D to stimulate expression of calbindin D changes with age in the rat. Archives of Biochemistry and Biophysics 352, 159-164.

Armbrecht HJ, Hodam TL, Boltz MA \& Kumar VB (1999) Capacity of a low calcium diet to induce the renal vitamin D $1 \alpha$-hydroxylase is decreased in adult rats. Archives of Biochemistry and Biophysics 255, 731-734.

Bar A \& Hurwitz S (1979) The interaction between dietary calcium and gonadal hormones in their effect on plasma calcium, bone, 25-hydroxycholecalciferol-1-hydroxylase, and duodenal calcium-binding protein, measured by a radioimmunoassay in chicks. Endocrinology 104, 1455-1460.

Bar A \& Hurwitz S (1981) Relationships between cholecalciferol metabolism and growth in chicks as modified by age, breed and diet. Journal of Nutrition 111, 399-404.

Bar A \& Hurwitz S (1987) Vitamin D metabolism and calbindin (calcium binding protein) in aged laying hens. Journal of Nutrition 117, 1775-1779.

Bar A, Maoz A \& Hurwitz S (1979) Relationship of intestinal and plasma calcium-binding protein to intestinal calcium absorption. FEBS Letters 102, 79-81.

Bar A, Rosenberg J \& Hurwitz S (1982) Plasma and intestinal content of 1,25 dihydroxyvitamin $\mathrm{D}_{3}$ in calcium or phosphorus restricted birds. Current Advances in Skeletongenesis. Proceeding of the 5th Workshop on Calcified Tissues, pp. 197-200 [M Silberman and HC Slavkin, editors]. Amsterdam: Elsevier Science Publishing.

Bar A, Shani M, Fullmer CS, Brindak ME \& Striem S (1990) Modulation of chick intestinal and renal calbindin gene expression by dietary vitamin $\mathrm{D}_{3}, 1,25$-dihydroxyvitamin $\mathrm{D}_{3}$, calcium and phosphorus. Molecular and Cellular Endocrinology 72, 23-31.

Christakos S (1996) Vitamin D gene regulation. In Principles of Bone Biology, pp. 435-446 [JP Bilezikian and GA Rodan, editors]. San Diego, CA: Academic Press Inc.
Duncan DB (1955) Multiple range and multiple F tests. Biometrics 11, 1-42.

Fitzpatrick LA \& Bilezikian JP (1996) Actions of parathyroid hormone. In Principles of Bone Biology, pp. 339-346 [JP Bilezikian, LG Raisz and GA Rodan, editors]. San Diego, CA: Academic Press Inc.

Friedlander EJ, Henry HL \& Norman AW (1977) Studies on the action of calciferol: Effect of dietary calcium and phosphorus on the relationship between the 25-hydroxylation $\mathrm{D}_{3}$-1ahydroxylase and production of chick intestinal calcium binding protein. Journal of Biological Chemistry 252, 8677-8683.

Gomori G (1942) Modification of the colorimetric phosphorus determination for use with photometric colorimeter. Journal of Laboratory and Clinical Medicine 27, 955-960.

Havenstein GB, Ferket PR, Scheideler SE \& Larson BT (1994) Growth, livability, and feed conversion of 1957 vs. 1991 broilers when fed "typical" 1957 and 1991 broiler diets. Poultry Science 73, 1785-1794.

Hunziker W, Walters MR, Bishop JE \& Norman AW (1982) Effect of vitamin D status on the equilibrium between occupied and unoccupied 1,25-dihydroxyvitamin D intestinal receptors in the chick. Journal of Clinical Investigation 69, 826-833.

Hurwitz S, Plavnik I, Shapiro A, Wax E, Talpaz H \& Bar A (1995) Calcium metabolism and requirements of chickens are affected by growth. Journal of Nutrition 125, $2679-2686$.

Kumar R (1997) Vitamin D and the kidney. In Vitamin D, pp. 275-292 [D Feldman, editor]. San Diego, CA: Academic Press Inc.

Mitchell RD \& Edwards HM (1996) Effects of phytase and 1,25dihydroxycholecalciferol on phytate utilization and the quantitative requirement for calcium and phosphorus in young broiler chickens. Poultry Science 75, 95-110.

Montecuccoli G, Bar A, Risenfeld G \& Hurwitz S (1977) The response of 25-hydroxycholecalciferol-1-hydroxylase activity, intestinal calcium absorption, and calcium-binding protein to phosphate deficiency in chicks. Comparative Biochemistry and Physiology 57A, 331-334.

Morrissey RL \& Wasserman RH (1971) Calcium absorption and calcium-binding protein in chicks on differing calcium and phosphorus intakes. American Journal of Physiology 220, $1509-1515$.

National Research Council (1994) Nutrient Requirements for Poultry, 9th ed. Washington, DC: National Academy Press.

Orban JI \& Roland DA (1990) Response of four broiler strains to dietary phosphorus above and below the requirement when brooded at two temperatures. Poultry Science 69, 440-445.

Page RK, Fletcher OJ \& Parshall B (1979) Calcium toxicosis in broiler chicks. Avian Diseases 24, 1055-1059.

Rao SVR \& Reddy VR (1999) Non-phytin phosphorus requirements of commercial broilers and White Leghorn layers. Animal Feed Science and Technology 80, 1-10.

Riddle C (1991) Developmental, metabolic, and miscellaneous disorders. In Diseases of Poultry, pp. 827-862 [BW Calnek, HJ Barnes, CW Beard, WM Reid and HW Yoder, editors]. Ames, IA: Iowa University Press.

Shafey TM, McDonald MW \& Pym RA (1990) Effects of dietary calcium, available phosphorus and vitamin $\mathrm{D}$ on growth rate, food utilization, plasma and bone constituents and calcium and phosphorus retention of commercial broiler strains. British Poultry Science 31, 587-602.

Snedecor GW \& Cochran WG (1967) Statistical Methods, 6th ed. Ames, IA: Iowa State University Press.

Sorensen P, Su G \& Kestin SC (2000) Effects of age and stocking density on leg weakness in broiler chickens. Poultry Science 79, 864-870.

Waldroup PW, Kersey JH, Saleh EA, Fritts CA, Yan F, 
Stilborn HL, Crum RC \& Raboy V (2000) Nonphytate phosphorus requirement and phosphorus excretion of broiler chicks fed diets composed of normal or high available phosphate corn with and without microbial phytase. Poultry Science 79, $1451-1459$.

Wasserman RH (1997) Vitamin D and the intestinal absorption of calcium and phosphorus. In Vitamin D, pp. 259-273 [D Feldman, editor]. San Diego, CA: Academic Press Inc.

Williams B, Waddington D, Solomon S \& Farquharson C (2000) Dietary effects on bone quality and turnover, and $\mathrm{Ca}$ and $\mathrm{P}$ metabolism in chickens. Research in Veterinary Science 69, 81-87. 